\title{
SMEs Financial Report: Between Quality and Access to Bank Credit
}

Andi Iswoyo, Yuli Ermawati, and Alf Nugroho

Accounting Department, Universitas Wijaya Putra, Surabaya, Indonesia

\section{Abstract}

Background: Indonesian Banks noted that only 22\% of SMEs have access to bank credits, and one of the main obstacles that they do not have is a good financial administration and management system. The aim of this study is to determine the perception and understanding of SMEs in compiling financial report in accordance with the Financial Accounting Standards for SMEs to facilitate in obtaining capital from the banks so as to improve the competitiveness of SMEs.

Materials and Methods: The data is obtained from the perception SMEs owners in some cities at East Java Indonesia, using survey as primary data. Data analysis was done using Partial Least Square to test the confirmatory factor analysis and $T$-test to test to

Corresponding Author:

Andi Iswoyo

andi@uwp.ac.id

Received: 29 January 2019 Accepted: 27 February 2019 Published: 24 March 2019

Publishing services provided by Knowledge E

(c) Andi Iswoyo et al. This article is distributed under the terms of the Creative Commons

Attribution License, which permits unrestricted use and redistribution provided that the original author and source are credited.

Selection and Peer-review unde the responsibility of the $3 r d$ ICEEBA Conference Committee.
G OPEN ACCESS determine the effect between variables, and interviews were conducted to strengthen the results of the study.

Results:The test results show that the entire outer loading construct indicator has a loading value more than 0.5 , thus meeting convergent validity. The discriminant validity result shows that the root square value of $A V E$ is greater than 0.5 . It is reliable because composite reliability values are above 0.7. For the inner models of Q-Square is greater than 0 , it can be interpreted that the latent predictor and the model can be estimated to be estimated. The results of the $t$-test show that the level and background of education, age, and size of the company influence the perception of SMEs about the importance of financial report. Information and socialization about financial report affect the perception and understanding of SMEs indicated by the $T$-test value of 23.725. Company age and size, credit terms, and collateral credit have a significant effect on bank credit, but the quality of financial statements has no effect on bank credit as indicated by the $T$-test of 0.291 because financial reports are generated by SMEs have not been tested and have not been able to reflect the real reality of SMEs.

Conclusion: The implementation of financial accounting standards for SMEs is still not felt by SMEs hampered due to the low perception and understanding of SMEs toward the prevailing accounting standards so that socialization is needed. The banking sector must provide learning to SMEs about the terms of credit provision through quality financial reports.

Keywords: financial accounting standard for SMEs, financial reporting, perception, ćccesstobanlcuiedii

The micro trade, small and medium enterprise then it is called UMKM in its development has increased and supported the growing of Indonesia economic continually. The role of the micro, small and medium enterprise through creating field jobs, spare employers 
and it also becomes the hand of economic by improving that it is still being existence in the middle of economic crisis. The micro, small and medium enterprise also has been proof that it was not influenced toward the crisis.

When the economic crisis had attacked in 1997 to 1998, only the micro, small and medium enterprise was capable being existence strongly. Based on the center statistics foundation data showed that, time after the economic crisis in 1997-1998 the number of the micro, small and medium enterprise was not gotten in reducing, even it got increasing continually, the fact that it could spare the employers reaching 85 till 107 million people till year 2012. In that year the number of entrepreneurs was estimating $\mathbf{5 6 . 5 3 9 . 5 6 0}$ unit. From those numbers of entrepreneurs, the micro, small and medium enterprise was 56.534 .592 unit or $99.99 \%$. For the big entrepreneurs reached $0,01 \%$ or 4.968 units. That data is as proving that the micro, small and medium enterprise is potential market for the financials service, especially for the banks that have function to distribute cost. Due to over 60 to $70 \%$ the entrepreneurs of the micro, small and medium enterprises have not accessed yet in accessing to bank credit. The financial of banks institution even active in giving the credit facilities to entrepreneurs of the micro, small and medium enterprises. The contributing of credit of financials to of the micro, small and medium enterprises sectors get growing even generally there is increasing more than banks credit.

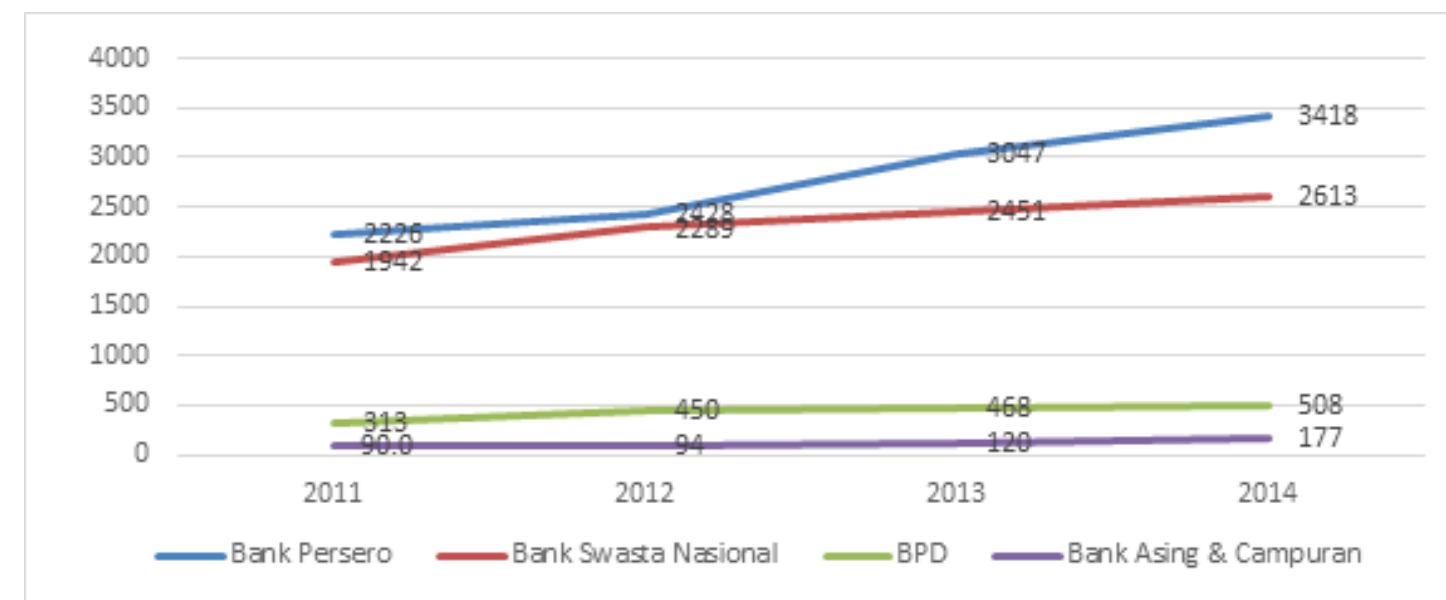

Figure 1: The distributing of credit to Micro, Small and Medium Enterprises owner by National Banks 20112014. (Source: Indonesia Bank, 2015.)

Figure above is as the data in 2014 that explained about the number credit distributing by banks sectors, where the big portion is still held by the Government Bank reached $50 \%$, while for the National Private Banks get the second position estimate 40\%, Development Regional Bank (BPD) had estimated 7\% and Foreign Banks and from mixing reached 3\% (Indonesia Banks, 2015). 
From the figure above, can be seen that there is increasing every year about credit distributing to the micro, small and medium enterprise by General Banks. From the quantity cases, Central Banks had distributed regulation of Indonesia Bank (PBI) No. 14/22/PBI/2012 date $21^{\text {st }}$ December 2012 about distributing of credits by General Banks and Technical Aid in development the micro, small and medium enterprise. Regulation of Indonesia Bank emphasized to the banks in order to in year 2015 gives portion credits at least $5 \%$ to the micro, small and medium enterprise from the total credits or distributing cost. Even in year 2018 credit ratio or the cost toward for the micro, small and medium enterprise decide the lower range $20 \%$ from total or cost. Then, from the quality cases, banking entrepreneur must understand the business profile for the micro, small and medium enterprise to get credit access deeply so the distributing exact places for the owners and result good quality credit and completely.

Indonesia Bank (BI) is as the central bank also active accompanying to the micro, small and medium enterprise to develop their enterprise. The assistance toward the micro, small and medium enterprise is done by giving workshop of technical financial report so the increasing highly competence. Till the second period in the three month first in 2016, after time the micro, small and medium enterprise credit gets increasing become $19,7 \%$ if it was compared in the first period in the month first 2016 reached 19,5\%. But Indonesia Bank noted that only $22 \%$ of the micro, small and medium enterprise that has accessing toward banking credit has not had financial administration system and good management (Adhi Candra, 2016).

Some researches had found that many the micro, small and medium enterprise in Indonesia have not arranged yet financial report well because the financial standard that it was still difficult so it had not applied yet by the micro, small and medium enterprise. In year 2013, the government created the regulation in laws number 1 year 2013 about micro financial institution (LKM) that it obligated in order to the micro financial institution can arrange the report about financial based on the accounting that conducted so it is needed the arrangement financial for micro financial institution. Based on the survey that had been done, Micro Financial Directorate Institution (DLKM) OJK, that observation operational activities of micro financial institution, from the data can concluded that many micro financial institution still use money supply by using manual notes and suggest in order to IAI can arrange accounting standard especially for micro financial institution. But, it is needed to know since 2009, IAI did not give accounting regulation for certain industries as the effect from convergence to The International Financial Reporting Standard (Anggraeni, 2016). 
DSAK IAI does development about accounting standard that can fulfill the need of micro, small and medium enterprise in forming of work group that included the industry association, regulator and other stockholders in attending Financial Accounting Standard (SAK) that it can support the development of the micro, small and medium enterprise in Indonesia. In the end of 2016, DSAK IAI had legaled SAK Entity of Micro Small and Medium Enterprise (EMKM) as the effort in supporting development of economic in Indonesia.

SAK entity of micro small and medium micro enterprise (EMKM) made accounting simple regulation from SAK ETAP because the managing of transaction in generally is done by entity of micro small and medium micro enterprise and the basic pure measuring uses history cost. SAK entity of micro small and medium micro enterprise are also supplied by the things that is not part from SAK entity of micro small and medium micro enterprise, namely Conclusion Basic (DK) and example of illustration. Conclusion Basic gives explanation based on background accounting regulation that decided by SAK EMKA. Example of illustrative gives implementation SAK entity of micro small and medium micro enterprise so it makes easier entity of micro small and medium micro enterprise. This SAK entity of micro small and medium micro enterprise is conducted in $1^{\text {st }}$ January 2018 but it is hoped to imply in the beginning.

In other side, the micro, small medium enterprise felt that it did not need information about accounting and said difficult to note accounting and only supposed as waste time and cost. The limitation of knowledge about the accounting for the micro, small, medium enterprise caused they did not practice about accounting process and it fulfil bases on SAK that used. No optimal the implement and complete accounting to the micro, small, medium enterprise are not optimal from government and for UMKM micro, small and medium enterprise. But, it is caused by it is not by the government and university $n$ supporting and give service in accounting the micro trade, small, medium enterprise (Kurniawanysah, 2016).

The result of research Iswoyo, Ermawati, Nugroho, Wilopo (2016) stated that micro trade, small and medium enterprise have had capability in making financial report and still more they only make noting about transaction because they are not able to count the exact taxes. The quality of financial reports is also influence toward to the number of accepting of credits by the micro trade, small and medium enterprise from the banking, while the prospect of implementation SAK entity of micro small and medium micro enterprise is getting problems in low of understanding entrepreneur micro trade, small and medium enterprise for SAK entity of micro small and medium micro enterprise, so they must arrange the accounting guide in process based on the SAK entity of micro small 
and medium micro enterprise that friendly users and systematically that is arranged by management micro trade, small and medium enterprise.

From the explanation of background above, researchers want to know how far the perception the entrepreneur of micro small and medium micro enterprise to implementation of SAK-EMKM, what are the obstacles in facing the arrangement financial reports, how does the arrangement of system information model in financial report and how do the way of draft of system hard ware information about financial report that easier the entrepreneur micro trade, small and medium enterprise in arranging the financial report in East Java. The model and hardware accounting system information make easier entrepreneurs in making based on the SAK entity of micro small and medium micro enterprise. That arrangement will make easier the entrepreneurs for getting credits from the bank or financial institution. From the background above can be formulated the obstacles or problems in the research, such as:

1. Do the education levels, background, periods of enterprise and measure enterprise influence toward the perception of entrepreneur the micro trade, small and medium enterprise toward the important of quality financial reports?

2. Do the education levels, background, periods of enterprise and measure enterprise, information and socialization about financial of literacy that given by government has influenced toward the understanding entrepreneurs of micro trade, small and medium enterprise toward the financial accounting standard for micro trade, small and medium enterprise?

3. Do the periods of enterprise, measure enterprise, number of credits, guarantee credits and quality financial reports has influenced toward giving credits of banking?

\section{Related Literatures}

Definition of the micro trade, small and medium enterprise (UMKM) based on the regulation of laws in Indonesia, in laws (UU) Number 20 year 2008 about micro trade, small and medium enterprise, namely:

1. Micro enterprise is an active of productive trade belongs individual and or firms individual that had fulfilled trading of criteria in micro enterprise, namely they have financial of heritage estimated 50 million net. It is not included the heritage of land and building of trading, or had had onset maximal 300 million each year. 
2. Small enterprise is the productive of economic enterprising that standing alone, which done by individual or firm that is not branch of company or part of company in which be owned, belong or becomes part company direct or indirectly from the medium or big enterprise that had fulfilled criteria small, namely have financial heritage more than 50 million till 500 million

3. Medium enterprise is the economic productive trade that stand by itself, in which done by individual or group of people that is not branch of company or part of company that be owned, mastered or become part of company directly or indirectly with small enterprise with financial heritage more than 500 million till 10 billion not included the land building heritage as the place enterprise or have turn over more than 2.5 billion till 50 billion each year

\subsection{Financial accounting standard entity micro, small and medium}

Financial Accounting Standard Entity Micro, Small and Medium and then called (SAK EMKM) is meant to be used by micro entity, small and medium. Entity micro, small and medium is entity without accountability public that significant, as that defined in Financial Accounting Standard Entity without accountability public (SAK ETAP), that fulfilled definition and criteria micro enterprise, small and medium as be regulated in laws in Indonesia at least two years late. (Indonesia Accounting Association, 2016). SAK EMKA can be used by entity that they have not had criteria above, if the priority gives permission to arrange financial report based on SAK financial accounting standard entity micro, small and medium.

SAK financial accounting standard entity micro, small and medium consists of accounting regulation that more simple from SAK ETAP because it manages the general transaction that done by micro enterprise, small and medium and pure basic measure uses history cost also completed by the things that is not part from SAK financial accounting standard entity micro, small and medium, namely Basic Conclusion that gives explanation the background in accounting regulation that it has decided by SAK financial accounting standard entity micro, small and medium and illustrative examples that given the implementation SAK financial accounting standard entity micro, small and medium so it can make easier financial accounting standard entity micro, small and medium in implementation this SAK. 


\subsection{Financial report for the micro, small and medium enterprise}

Financial report is a financial information notes in a company at one accounting that can be used to describe work system the company (Indonesia Accounting Association). The quality of financial report can be seen how far the financial report in giving describing that it can give right and honest information. Financial report that has quality in implementation information about the position of financial and work position in entity that have advantage for all users economic policy by everyone that they have role asking financial report to fulfill the need information. The users include the supplying human resource for entity, such as creditor's even investors. In fulfilling the purpose, the financial report also shows the reasonability for human resource that given to creditors and investors.

The purpose financial is to supply position financial information and financial works in entity that have advantage for the users in taking economics decision that done by everyone that they can ask financial report especially to get that information. The users included the suppliers human resource for entity as creditors or even investors. In full the purpose, the financial also shows responsibility that given to creditors and investors. (Indonesia Accounting Association

\subsection{Recent researchers}

The recent research was done by Iswoyo, Ermawati, Nugroho and Wilopo (2016) with title "Review of the Implementation of Government Regulation No. 46 Year 2013: Contributions and Constraint for SMEs." The result of research showed that, generally, the actors in the micro trade, small and medium enterprises are as the informant aware that they must state that the responsibility letters (SPT) must do on the time even though they do not understand the way of counting of taxes that being loaded to them. There are some the actors or entrepreneurs of micro trade, small and medium enterprises which keep on effort to understand the regulation of taxes with attending the socialization or workshop which held by taxes department or government taxes institution or other institutions. The obstacles that they face concern incapability in arranging and dishing up the financial reports well so it is needed the simple software in arrangement.

Narsa, and others (2012) did research by the title "Uncover Readability UMKM in the Implementation of Financial Accounting Standard without Public Accountable (PSAKETAP) to increase Banking Modal Access." That research was focused on the understanding about readability micro trade, small and medium enterprises in the implementation SAK ETAP. The essence of focusing as the aim is how far the micro trade, small and 
medium enterprises understand the useful of financial report that be arranged based on the fix of accounting financial standard. In that research is used qualitative approach or other alternative approaches. The method research that used is in-depth interview. Result of research was found that obstacles of the micro trade, small and medium enterprises did not have financial report based on the SAK-ETAP standard and the micro trade, small and medium enterprises that have financial notes well in which have development faster than the micro trade, small and medium enterprises even younger from other micro trade, small and medium enterprises older. One thing that had supported the development the micro trade, small and medium enterprise is capable of in credit access from the banking, so the problem of obstacles in financial can be overcame, even the turnover in year 2010 reached more than 800 billion with net profit after reducing operational cost and other cost reached from 100 billion.

\subsection{Researches hypothesis}

H1. The level of education is influence to perception owners of micro trade, small and medium enterprises toward the important of quality financial report.

$H 2$. The background of education has influence to the perception of the owners' micro trade, small and medium enterprises toward the important of quality financial report.

H3. Period of Establishing Enterprise has influence to the owners' micro trade, small and medium enterprises toward the important of quality financial report.

H4. Measuring Enterprise has influence to perception the owners' micro trade, small and medium enterprises toward the important of quality financial report.

H5. The level of Education has influence to the owners toward the understanding financial Report based on SAK-EMKM

H6. The background education has influence to the owners toward the understanding financial Report based on SAK-EMKM

H7. Periods of Establishing enterprise has influence to the owners toward the understanding financial Report based on SAK-EMKM

H8. Measuring Enterprise does not have influence the owners toward the understanding financial Report based on SAK-EMKM

H9. Information and socialization are about literacy of financial that given by government in understanding for the owner's UMKM 
H10. The long of firm establishing have significant influence toward giving of credit by banking.

H11. Measuring have significant influence toward giving of credit by banking.

H12. The credit of reaching influenced toward the significant for credit distributing by the banking.

H13. The guarantee of credits has significant influenced toward distributing of credit by the banking.

H14. The quality of finance report is not influence toward the credit distributing by the banking.

\section{Research Methods}

\subsection{Research approaches}

This research used the qualitative approaches that mixed with quantitative approaches if this research is seen from the kind data and the way in analysis. Quantitative data, especially to know the perception of entrepreneurs of micro trade, small and medium enterprises toward the financial accounting of micro entity, small trade and medium enterprise (SAK EMKM) and the obstacles that be faced by the entrepreneurs of the micro trade, small and medium enterprises in arrangement and present the financial reports that it is based on the formulas in SAK EMKM through survey method in order to obtained the data in representative one. The qualitative approach is used to deep examining about the comprehending and the obstacle that must be distributed the taxes of the micro trade, small and medium enterprises and arrange the information system model report that easier the entrepreneurs of micro trade, small and medium enterprises in arrange and present the quality financial report.

\subsection{Obtaining method data and location of research}

The population in this researchers are all entrepreneurs the micro trade, small and medium enterprises in East Java. The data is from Cooperation Department and the micro trade, small and medium enterprises Province of East Java, being reached 6.825.931 entrepreneur of the micro trade, small and medium enterprises that are separated in East Java (Cooperation and UMKM East Java, 2017). The technique in obtaining sample of data is used decide the micro trade, small and medium enterprises 
(UMKM) in Regional/City included in classification high growth and high income, namely Regency/City with the average PDRB per capita above the average PDRB per capita in Province of East Java and the economic growing above the average in East Java. From the Statistic Institution Centre or BPS (2015), it was obtained the data from 6 Regency/City that have the average PDRB per capita and the economic growing above Province of East Java. Six regencies/cities are Gresik, Mojokerto, Batu City, Madiun, Malang and Surabaya city. The decision of UMKM, the informant and the informants are chosen based on the purpose technique with the consideration criterion based on selection, where UMKM, the informants and the informants are decided by themselves by the researchers with consideration in getting information and the data needed.

\section{Result and Output Reaching}

The examining data is obtained the descriptive data as describing of profile about research informants based on the criterion that present in the table below:

TABLE 1: Researching informants.

\begin{tabular}{l|l|c|c|} 
No. & Regencies/Cities & $\begin{array}{c}\text { Economics } \\
\text { Entrepreneurs \& } \\
\text { UMKM }\end{array}$ & $\begin{array}{c}\text { Entrepreneurs of } \\
\text { UMKM }\end{array}$ \\
\hline 1 & Surabaya City & 2 & 6 \\
\hline 2 & Batu City & 2 & 5 \\
\hline 3 & Malang City & 2 & 6 \\
\hline 4 & Madiun City & 2 & 5 \\
\hline 5 & Regency of Mojokerto & 2 & 7 \\
\hline 6 & Regency of Gresik & 2 & 9 \\
\hline \multicolumn{2}{l}{ Total } & 12 & 38 \\
\hline
\end{tabular}

Based on the data above, can be seen that all informants in this research reaches 50 people in which into categories 12 people as the employees in department of economic entrepreneurs and the micro trade, small and medium enterprises of regencies/cities and 38 entrepreneurs from regencies/cities that have object of researches. The choosing of entrepreneurs in the micro trade, small and medium enterprises based on recommendation from the Economic Entrepreneur Department and the micro trade, small and medium enterprises regencies/cities that being in cities/regencies and based on the choosing the researchers that fulfill criterion based on the object in which that made easier for the researchers and the limit of time. 
Based on the education levels and background/department, the entrepreneurs informants UMKM can be divided based on the table below:

TABLE 2: Informants based on education background levels.

\begin{tabular}{l|c|c|c|c|c|}
\hline Education & \multicolumn{4}{|c|}{ Background Education } & Total \\
\hline SMA/SMK & Accounting & Management & Economic & Others & \\
\hline S1 & 0 & 0 & 0 & 11 & 11 \\
\hline Other & 5 & 7 & 5 & 5 & 22 \\
\hline Total & 0 & 0 & 0 & 5 & 5 \\
\hline Source: Primary data be processed, 2018. & $\mathbf{5}$ & $\mathbf{7}$ & $\mathbf{2 1}$ & $\mathbf{3 8}$ \\
\hline
\end{tabular}

Table above describes that part of respondent is bachelor degree, namely 22 people. For other who have background entrepreneurs in bachelors of entrepreneur are 5 people in accounting department, management 7 people. Economics background 5 people. The data is very important concerns to the perception for the entrepreneurs UKMK toward financial reports based on the SAK-EMKM. The data above is that the informant who graduated from senior high school/vocational school reaches 11 people and other graduation reaches 5 people.

TABLE 3: Informants based on the Asset and Selling every year.

\begin{tabular}{l|c|c|c|c|c|}
\hline Asset & \multicolumn{4}{c|}{ The Selling Each Year } & Total \\
\hline & $\begin{array}{l}\mathbf{1 0 0} \\
\text { million }\end{array}$ & $\begin{array}{c}\mathbf{1 0 0 - 4 9 9} \\
\text { million }\end{array}$ & $\begin{array}{c}\mathbf{5 0 0} \text { million-2.5 } \\
\text { billion }\end{array}$ & $\begin{array}{c}\mathbf{2} \mathbf{2 . 5} \\
\text { billion }\end{array}$ & \\
\hline$<100$ million & 6 & 0 & 0 & 0 & 6 \\
\hline $100-499$ million & 5 & 11 & 4 & 0 & 20 \\
\hline 500 million-2.5 billion & 0 & 0 & 7 & 5 & 12 \\
\hline Total & $\mathbf{1 1}$ & $\mathbf{1 1}$ & $\mathbf{1 1}$ & $\mathbf{5}$ & $\mathbf{3 8}$ \\
\hline Source: Primary data processed, 2018. & & & & \\
\hline
\end{tabular}

TABLE 4: Informant micro enterprise.

\begin{tabular}{|l|c|c|c|}
\hline Modal & \multicolumn{2}{|c|}{ Ever Borrow to Bank } & Total \\
\hline & Ever & Never & \\
\hline 100\% Personal Model & 0 & 10 & 10 \\
\hline 75-95\% Personal Model & 8 & 5 & 13 \\
\hline 50-74\% Personal Model & 10 & 0 & 10 \\
\hline$<50 \%$ personal Modal & 5 & 0 & 5 \\
\hline Total & $\mathbf{2 3}$ & $\mathbf{1 5}$ & $\mathbf{3 8}$ \\
\hline Source: Primary Data processed, 2018. & & \\
\hline
\end{tabular}


Based on the table above, can be known that mostly of informants ever did transaction of borrowing in banks with estimate 23 informants or $60,5 \%$ while the other with number 15 informants or $39,5 \%$ have not did transaction in the banking.

The result of processing data also got that mostly informants felt that arrangement financial report is important for development the trade or entrepreneur namely 24 people or $63,2 \%$ while the other 14 people or $36,8 \%$ felt

\section{Result of Research}

\subsection{Confirmatory factor analysis}

Based on the aim and specification of research, it had done examining with some steps or literary used software SmartPLS 2, to get the fix result of examining.

Below is the draft of research.

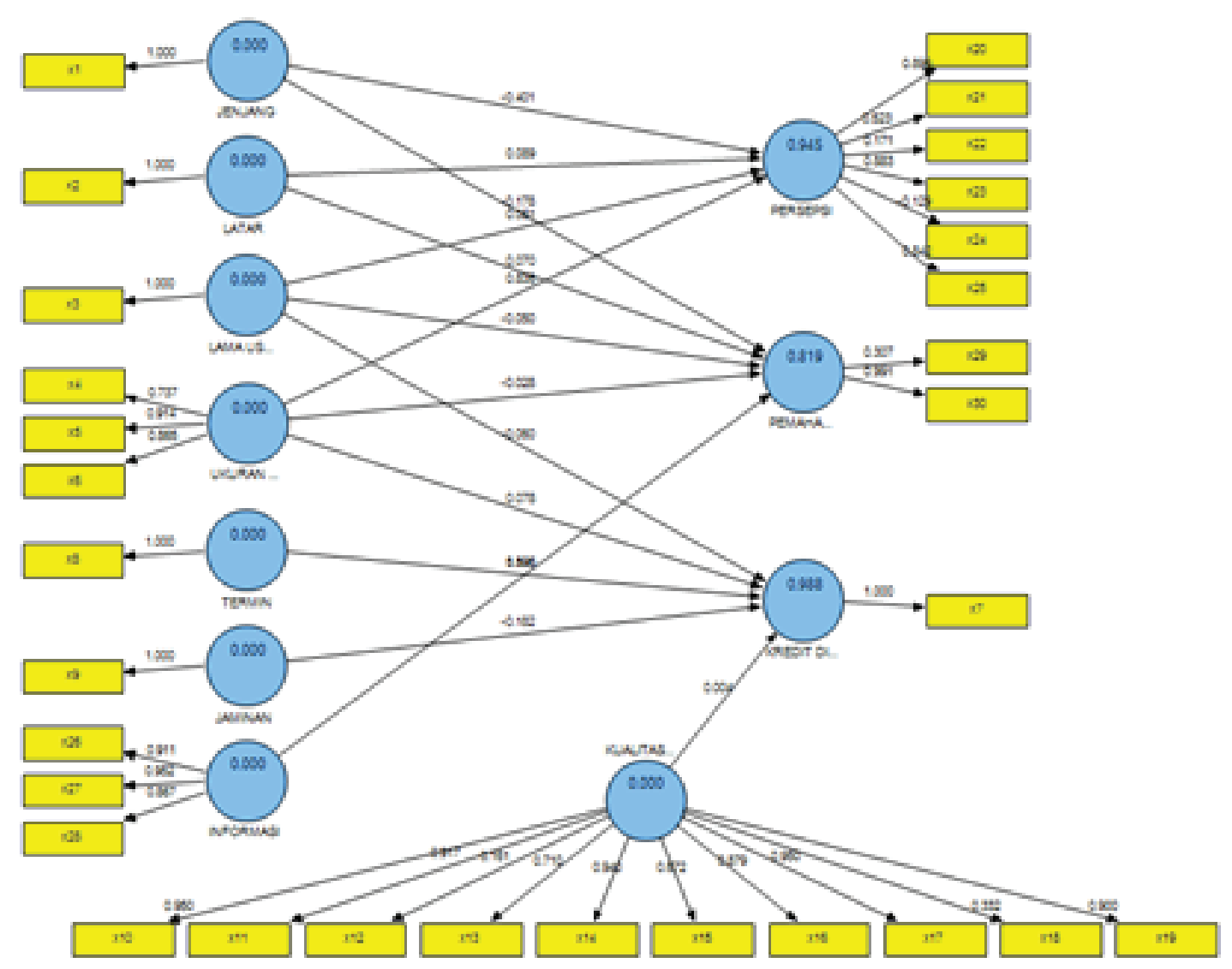

Figure 2: Confirmatory Factor Analysis Step 1.

Based on the figure above and see the enclosing the result of confirmatory factors in the first step can be described as the table below: 
TABLE 5: Evaluation Criterion Index Appropriate Models.

\begin{tabular}{|c|c|c|c|c|}
\hline Criteria & \multicolumn{2}{|c|}{ Hasil } & Nilai Kritis & Evaluation Model \\
\hline \multicolumn{5}{|l|}{ Outer Model } \\
\hline \multirow[t]{31}{*}{ Convergent Validity } & Indicator & Construct & $\geq 0.5$ & $\begin{array}{l}x 12, \times 18, x 22, \times 24 \\
\text { dan } \times 29 \text { di drop }\end{array}$ \\
\hline & $\mathrm{x} 1$ & 1.000 & & \\
\hline & $x 2$ & 1.000 & & \\
\hline & $x 3$ & 1.000 & & \\
\hline & $x 4$ & 0.737 & & \\
\hline & x5 & 0.914 & & \\
\hline & $x 6$ & 0.865 & & \\
\hline & $x 7$ & 1.000 & & \\
\hline & $x 8$ & 1.000 & & \\
\hline & $x 9$ & 1.000 & & \\
\hline & $x 10$ & 0.950 & & \\
\hline & x11 & 0.917 & & \\
\hline & $x 12$ & 0.161 & & \\
\hline & $x 13$ & 0.710 & & \\
\hline & $x 14$ & 0.940 & & \\
\hline & x15 & 0.672 & & \\
\hline & $x 16$ & 0.879 & & \\
\hline & x17 & 0.950 & & \\
\hline & $x 18$ & 0.332 & & \\
\hline & $x 19$ & 0.900 & & \\
\hline & $\times 20$ & 0.899 & & \\
\hline & $x 21$ & 0.523 & & \\
\hline & $\times 22$ & 0.171 & & \\
\hline & $\times 23$ & 0.883 & & \\
\hline & $\times 24$ & -0.129 & & \\
\hline & $\times 25$ & 0.842 & & \\
\hline & $\times 26$ & 0.911 & & \\
\hline & $\times 27$ & 0.952 & & \\
\hline & $\times 28$ & 0.867 & & \\
\hline & $\times 29$ & 0.307 & & \\
\hline & x30 & 0.991 & & \\
\hline
\end{tabular}

The result of appropriate model in conceptual in Table 5shown that there are 3 variables that had in which had loading factors they had score under 0,5 so the indicators that drops from research model is $\times 12, \times 18, \times 22, \times 24$ and $\times 29$ in the drop. 
After to be drop, the done Confirmatory Factor Analysis toward result research model after get output the variable that had loading factors less from 0,5 and can be gotten data as shown in this figure:

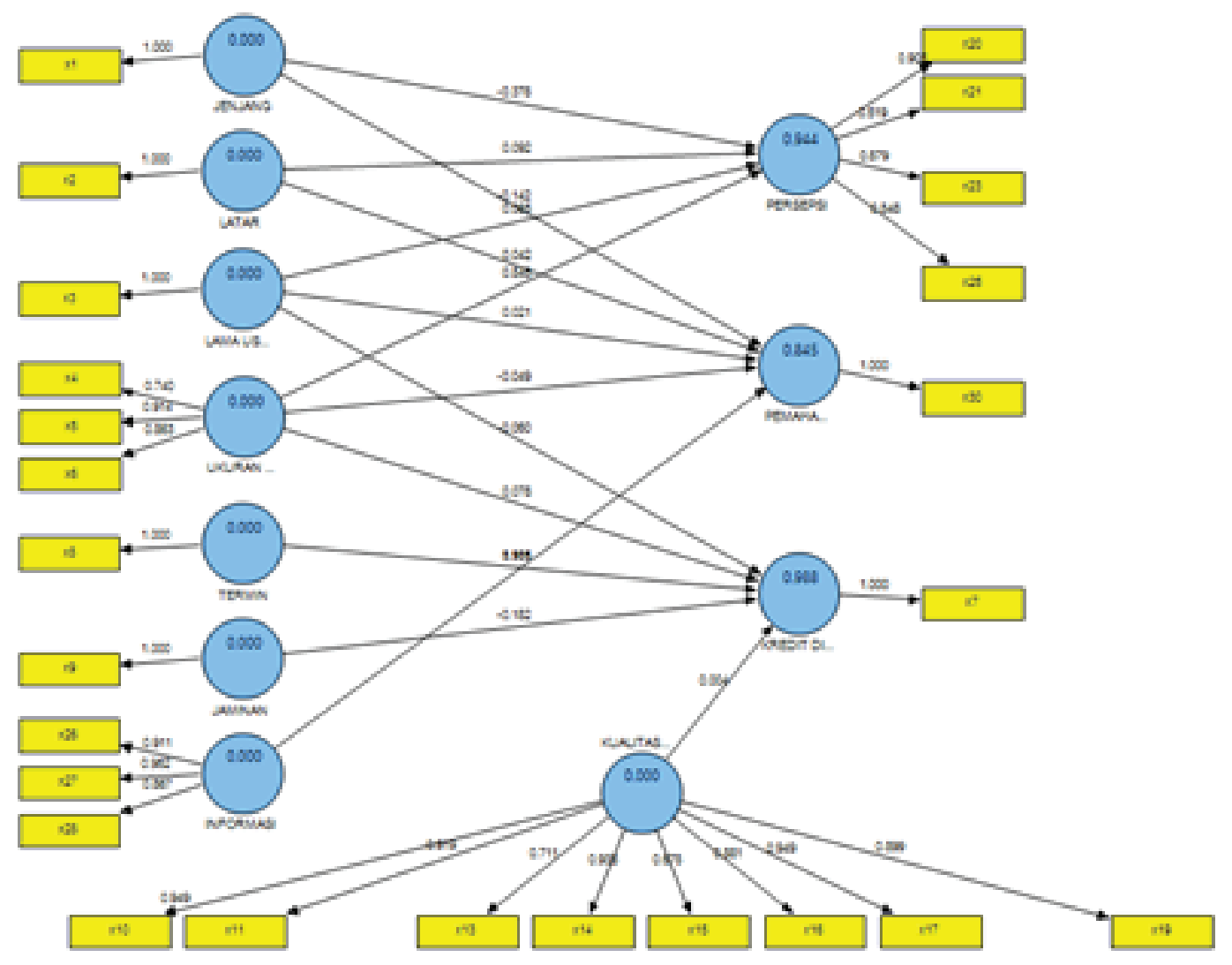

Figure 3: Confirmatory Factor Analysis Steps 2.

Based on the figure above can be seen enclosing result Confirmatory Factor Analysis the second step can be described as table below:

TABLE 6: Work Evaluation Criterion Appropriate Index Model (2).

\begin{tabular}{|c|c|c|c|}
\hline $\begin{array}{l}\text { Criteria } \\
\text { Outer Model }\end{array}$ & \multicolumn{2}{|c|}{ Hasil } & $\begin{array}{c}\text { Nilai Kritis } \\
\text { Evaluation Model }\end{array}$ \\
\hline Convergent Validity & Indicator & Construct & \\
\hline & $\mathrm{x} 1$ & 1.000 & \\
\hline & $x 2$ & 1.000 & \\
\hline & $x 3$ & 1.000 & \\
\hline & $x 4$ & 0.740 & \\
\hline & $x 5$ & 0.914 & \\
\hline & $x 6$ & 0.863 & \\
\hline & $x 7$ & 1.000 & \\
\hline & $x 8$ & 1.000 & \\
\hline
\end{tabular}




\begin{tabular}{|c|c|c|c|c|c|}
\hline \multirow[t]{18}{*}{ Criteria } & & Hasil & & & Nilai Kritis \\
\hline & $x 9$ & & 1.000 & & \multirow{17}{*}{$\geq 0.5$ Baik } \\
\hline & $x 10$ & & 0.949 & & \\
\hline & $\mathrm{x} 11$ & & 0.919 & & \\
\hline & $x 13$ & & 0.711 & & \\
\hline & $x 14$ & & 0.938 & & \\
\hline & x15 & & 0.678 & & \\
\hline & $x 16$ & & 0.881 & & \\
\hline & $x 17$ & & 0.949 & & \\
\hline & x19 & & 0.899 & & \\
\hline & $x 20$ & & 0.903 & & \\
\hline & $x 21$ & & 0.519 & & \\
\hline & $x 23$ & & 0.879 & & \\
\hline & $x 25$ & & 0.848 & & \\
\hline & $x 26$ & & 0.911 & & \\
\hline & $\times 27$ & & 0.952 & & \\
\hline & $x 28$ & & 0.867 & & \\
\hline & x30 & & 1.000 & & \\
\hline \multirow{12}{*}{$\begin{array}{l}\text { Discriminant validity } \\
\text { (Average Variance } \\
\text { Extracted (AVE) setiap } \\
\text { konstruk lebih besar } \\
\text { daripada nilai korelasi } \\
\text { antara konstruk) }\end{array}$} & & AVE & & $\begin{array}{c}\text { Rootsquare } \\
\text { AVE }\end{array}$ & \\
\hline & Informasi & 0.830 & & 0.911 & \multirow{11}{*}{$\geq 0.5$ Baik } \\
\hline & Jaminan & 1.000 & & 1.000 & \\
\hline & Jenjang & 1.000 & & 1.000 & \\
\hline & $\begin{array}{c}\text { Kredit } \\
\text { Disetujui }\end{array}$ & 1.000 & & 1.000 & \\
\hline & Kualitas Lap & 0.760 & & 0.872 & \\
\hline & Lama Usaha & 1.000 & & 1.000 & \\
\hline & Latar & 1.000 & & 1.000 & \\
\hline & Pemahaman & 1.000 & & 1.000 & \\
\hline & Persepsi & 0.644 & & 0.803 & \\
\hline & Termin & 1.000 & & 1.000 & \\
\hline & $\begin{array}{l}\text { Ukuran } \\
\text { Usaha }\end{array}$ & 0.709 & & 0.842 & \\
\hline \multirow{4}{*}{$\begin{array}{l}\text { Composite Reliability } \\
(\rho c)\end{array}$} & Informasi & & 0.936 & & \\
\hline & Jaminan & & 1.000 & & \\
\hline & Jenjang & & 1.000 & & \\
\hline & $\begin{array}{c}\text { Kredit } \\
\text { Disetujui }\end{array}$ & & 1.000 & & \\
\hline
\end{tabular}




\begin{tabular}{|c|c|c|c|}
\hline \multirow[t]{2}{*}{ Criteria } & \multicolumn{2}{|c|}{ Hasil } & \multirow{2}{*}{$\begin{array}{c}\text { Nilai Kritis } \\
\text { Evaluation Model }\end{array}$} \\
\hline & Kualitas Lap & 0.961 & \\
\hline & Lama Usaha & 1.000 & \multirow{6}{*}{$\geq 0,7$ Baik } \\
\hline & Latar & 1.000 & \\
\hline & Pemahaman & 1.000 & \\
\hline & Perception & 0.875 & \\
\hline & Reaching & 1.000 & \\
\hline & $\begin{array}{l}\text { Measure } \\
\text { Enterprise }\end{array}$ & 0.879 & \\
\hline \multicolumn{4}{|c|}{ Inner Model } \\
\hline \multirow[t]{3}{*}{ Q-Square } & $\begin{array}{l}\text { Approval } \\
\text { Credit }\end{array}$ & 0.774 & \multirow{3}{*}{$\geq 0.0$ Well } \\
\hline & Understandinç & 0.521 & \\
\hline & Perception & 0.470 & \\
\hline
\end{tabular}

Examining Result based on the table shows that all utter loadings construct indicator has value loading $>0.5$, so can be concluded the measuring requires the validity convergence. Result of discriminant validity shows that value root square of average variance extracted (AVE) more than 0.5 . Result of reliability examining shows that the reliability variable because of the value of composite reliability $(\rho c)$ above 0,7 . For inner model Q-Square more than 0 so can be interpret that predictor later so can be said that model is suitable can be estimated.

\subsection{Regency analysis}

Result examining that done toward the effect influence between construct as describe the draft of conceptual that can be developed by result analysis smartPIs 2 in the final step so it makes easier to see the simple one can be draw between construct as Figure 4.

The result from examining is with smartPls 2 can be interpreted result examining to fourteen hypothesis result that can be submitted in this result as explanation below:

TABLE 7: Result of Hypothesis Examining.

$\begin{array}{llccc}\text { H } & \text { Influence } & \begin{array}{c}\text { Koef } \\ \text { Path }\end{array} & \text { T-Counting } & \text { Adverbs } \\ \text { H1 } & \text { Levels } \rightarrow \text { Perception } & -0.378 & 6.081 & \text { Significant* } \\ \text { H2 } & \text { Background } \rightarrow \text { Perception } & 0.092 & 4.247 & \text { Significant* } \\ \text { H3 } & \text { Period Trade } \rightarrow \text { Perception } & 0.065 & 2.286 & \text { Significant }^{* *} \\ \text { H4 } & \text { Measure Trade } \rightarrow \text { Perception } & 0.848 & 16.903 & \text { Significant* }^{*}\end{array}$




$\begin{array}{llccc}\text { H } & \text { Influence } & \begin{array}{c}\text { Koef } \\ \text { Path }\end{array} & \text { T-Counting } & \text { Adverbs } \\ \text { H5 } & \text { Levels } \rightarrow \text { Understanding } & -0.142 & 2.108 & \text { Signifcant }^{* *} \\ \text { H6 } & \text { Background } \rightarrow \text { Understanding } & 0.042 & 1.422 & \text { Significant }{ }^{* * *} \\ \text { H7 } & \text { Period Trade } \rightarrow \text { Understanding } & 0.021 & 0.438 & \text { Not Significant } \\ \text { H8 } & \text { Measure Trade } \rightarrow \text { Understanding } & -0.049 & 0.875 & \text { Not Significant } \\ \text { H9 } & \text { Information } \rightarrow \text { Understanding } & 0.911 & 23.725 & \text { Significant }{ }^{*} \\ \text { H10 } & \text { Period Trade } \rightarrow \text { Approval Credits } & -0.060 & 3.990 & \text { Significant * } \\ \text { H11 } & \text { Measure Trade } \rightarrow \text { Approval Credits } & 0.078 & 4.924 & \text { Significant * } \\ \text { H12 } & \text { Reaching } \rightarrow \text { Approval Credits } & 1.105 & 37.663 & \text { Significant * } \\ \text { H13 } & \text { Guarantee } \rightarrow \text { Approval Credits } & -0.182 & 6.166 & \text { Significant } \\ \text { H14 } & \text { Quality Field } \rightarrow \text { Approval Credits } & 0.004 & 0.291 & \text { Not Significant }\end{array}$

Note: * significant in level $1 \%$, score $t$ at the level $1 \%=2.428$; ${ }^{* *}$ significant in level $5 \%$, score $t$ at the table level $5 \%=1.686 ;{ }^{* * *}$ significant in level $10 \%$, score $t$ at the table level $10 \%=1.304$.

Source: Result processing primary data (2018).

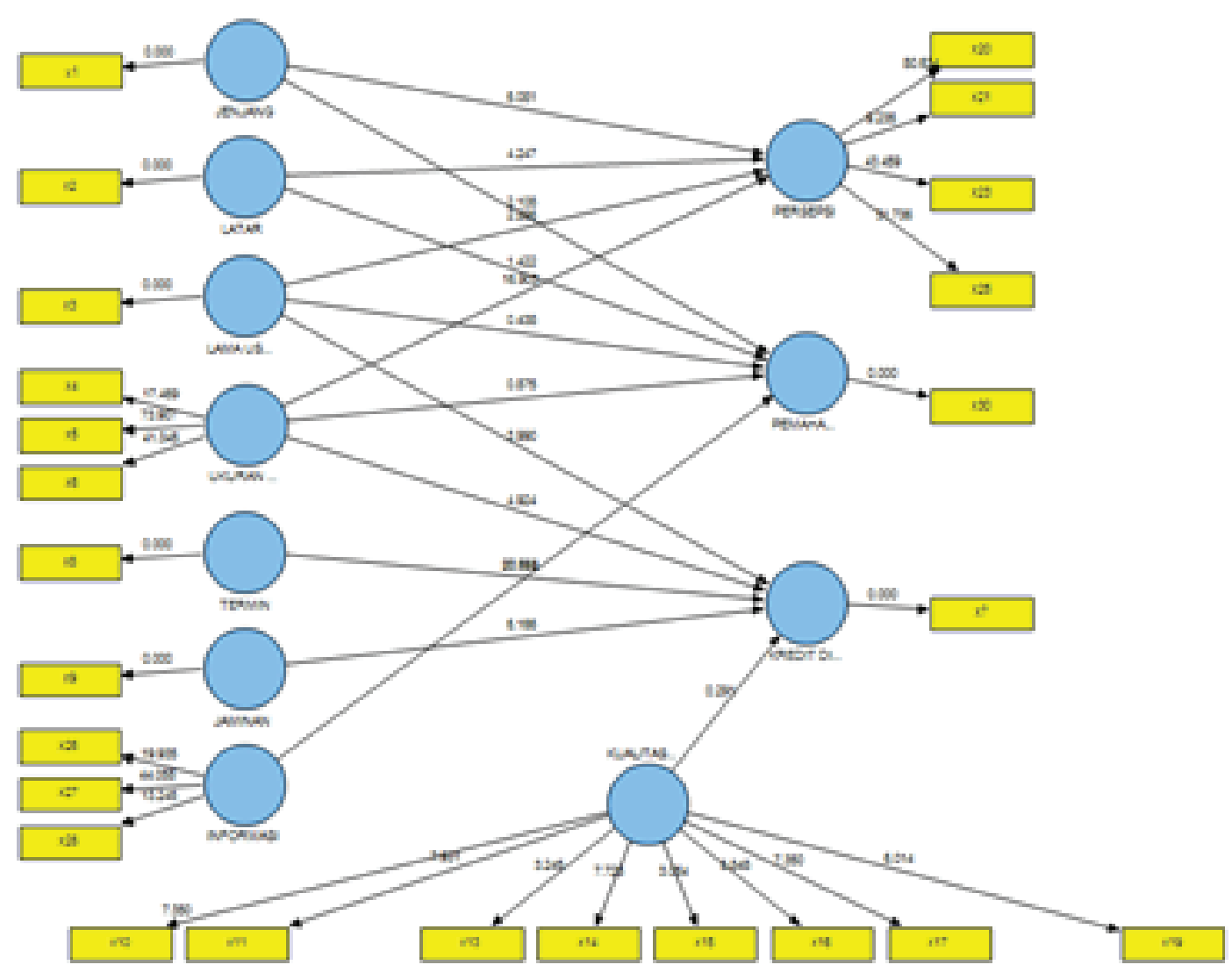

Figure 4: Path Coefficients (Mean, STDEV, T-Values). 
Result of examining with compare score $t$ counted with score $t$-table, if score $t$-count bigger from $t$-table so the relationship between significant construct and it can be analyze more. The interpretation from the result toward 14 hypothesis of result submitting in this result as below:

1. Level of education influences toward perception of entrepreneurs of the micro trade, small and medium enterprise, as shown in coefficient score reaggregation estimating -0.378 and score $T$ counted estimating 6.081 bigger from $T$-table $=$ 2.428 significant in the level $1 \%$. So the higher education will influence the high perception entrepreneurs of the micro trade, small and medium enterprise toward financial arrangement report based on SAK-EMKM. This case can be concluded that $\mathrm{H} 1$ is accepted

2. Background of education influenced toward the perception entrepreneurs the micro trade, small and medium enterprise, That is shown the value coefficient reaggregation estimate 0,092 and value $T$-big count estimate 4.247 bigger than $T$ as in table $=2.428$ significant level on the table $1 \%$. So it was appropriate that the background for entrepreneurs of the micro trade, small and medium enterprise will influence for perception toward the important note and finance report for their enterprise. It can be concluded that $\mathrm{H} 2$ is accepted.

3. Long of establish toward perception entrepreneurs of the micro trade, small and medium enterprise, is shown with the coefficient value regression estimate 0,065 and value $T$ counted with nominal 2.286 bigger than in table $T=2.428$ significant in the level $1 \%$. So the old the age of company will have big influence for perception entrepreneurs of the micro trade, small and medium enterprise toward the bookkeeping and financial report. It can be concluded that $\mathrm{H} 3$ is accepted.

4. The measure has influenced toward the perception entrepreneurs of the micro trade, small and medium enterprise that shown by the regression coefficient value estimate 0,848 and value $T$ reach 16.90 bigger 16.903 bigger than table $T=2.428$ significant in level $1 \%$. So the bigger measure will influence in the high perception entrepreneurs of the micro trade, small and medium enterprise toward the bookkeeping and financial report for their company. It can be concluded that $\mathrm{H} 4$ is accepted.

5. The level of education influence toward understanding the entrepreneurs toward arrangement finance report based on SAK-EMKM, shown with regression coefficient value reach -0.142 and value for $T$ counted reach 2.108 bigger than value $T$ in 
the table $=1.686$ significant in the level $5 \%$. So the high education the micro trade, small and medium enterprise will influence the high education in understanding of the micro trade, small and medium enterprise toward the arrangement finance report based on SAK-EMKM. It can be concluded that H5 is accepted.

6. The background of education influence toward understanding the micro trade, small and medium enterprise toward the arrangement finance report based on SAK-EMKM, that is shown with the coefficient value regression estimate 0.042 and value $T$ counted estimate 1.422 bigger than from $T$ in the table $=1.304$ significant in the level $10 \%$. So the more of appropriate education for the micro trade, small and medium enterprise will influence in the understanding about arrangement finance report based on SAK-EMKM. It can be concluded that $\mathrm{H} 6$ is accepted.

7. Long of establishing firm is not influence toward the entrepreneurs to the arrangement finance report based on SAK-EMKM, shown with regression coefficient value reach 0,021 and value $T$ counted estimate 0.438 smaller than $T$ in the table $=$ 1.304 that is not significant in the level $10 \%$. So older of establishing company is not influence toward the high of understanding the micro trade, small and medium enterprise toward arrangement finance report based on SAK-EMKM. It can be concluded that $\mathrm{H} 7$ is accepted.

8. The measure of trade is not influence arrangement finance report based on SAKEMKM, shown with values with regression coefficient value reach -0.049 and value $T$ counted estimate 0,875 smaller than $T$ in the table $=1.304$ is not significant on the level $10 \%$. So bigger of measure of company is not influence toward high understanding the micro trade, small and medium enterprise toward arrangement finance report based on SAK-EMKM. It can be concluded that $\mathrm{H} 8$ is accepted.

9. Information and socialization are about financial literacy that was given by government has influenced toward understanding the micro trade, small and medium enterprise, shown with value of coefficient regression reach 0,911 and value $T$ in the table $=2.428$ significant on the level $1 \%$. So the frequency of government in given Information and socialization about the standard financial accounting for small entrepreneurs will influence for the high in understanding the micro trade, small and medium enterprises toward arrangement finance report based on SAKEMKM. It can be concluded that $\mathrm{H} 9$ is accepted.

10. The old of enterprise is not influence significant toward the giving credit by banking, shown by coefficient value regression estimate -0.060 and value $T$ counted 
estimate 3.990 bigger than value $T$ in the table $=2.428$ significant in the level $1 \%$. So the older the company establishing will influence toward higher for giving credit by banking. It can be concluded that $\mathrm{H} 10$ is accepted.

11. The measuring of enterprise influence significant to distribute financial by the bank that shown with coefficient regression value estimate 0,078 and value $T$ counted 4.924 bigger than $T$ on the table $=2.428$ significant in the level $1 \%$. So bigger the capability the company will influence to high giving of credit by banking. It can be concluded that $\mathrm{H} 11$ is accepted.

12. Accepting of credit influence significant for giver of credit by banking. That is shown by coefficient value regression estimate 1.105 and value $T$ counted estimate 2.428 significant in the level $1 \%$. So older of frequency of credit that submittee is request the higher decision of giving credit by banking institution. It can be concluded that $\mathrm{H} 12$ is accepted.

13. Guarantee of credit influence toward giving credit by banking, shown with coefficient regression estimate -0.182 and value $T$ counted 6.166 bigger than in the table $T=1.428$ significant on the level $1 \&$. So bigger of guarantee of credit that accepting will influence toward the decision of giving by the bank owners. It can be concluded that $\mathrm{H} 13$ is accepted.

14. The quality of financial report is not influence toward the distributing of credit by banks, in which is shown with the value of coefficient regression in number 0.004 and value $T$ be counted estimate 0.291 smaller than $T$ in table $=1.304$ not significant in the level $10 \%$. So the better of quality of finance report will influence in the high of distributing payment or credit by the bank institution. It can be concluded that $\mathrm{H} 14$ is accepted.

\section{Discussion}

\subsection{The perception of the micro trade, small and medium enterprises (UMKM) toward the important bookkeeping and financial report for its enterprise}

The entrepreneurs of the micro trade, small and medium enterprises feel bookkeeping and financial reports are very important for their enterprises. From the table 5.8 above is mostly informant felt that arrangement the financial report very important for development their enterprise reach 24 people or 63,2 while the other is 14 people or $36,8 \%$ felt 
less important. From that data, it can be proved well that part of informant need to know the financing report well based formula of accounting. The need is probably appeared because their needs to get credit from banking that required of financing report as the proof the running of company that is being running well.

From analysis regression above, can be found that level education, the background, the age period of company and measure company influence in significant toward perception the micro trade, small and medium enterprises to the important of arrangement financial report well based on the standard of roles such SAK-EMKM due to part of informants (22 people or $57.9 \%$ ) have bachelor degrees, so they felt that higher education the level of education will be high too perception them in toward the important the arrangement financial report well and right based the standard of SAK-EMKM.

The background of education is also influence to the important in arrangement financial report well and right based on the standard that requires in SAK-EMKM, that is probably due to there is not many informant that are from the Accounting Department, but they were supposed that older education appropriate in education levels, so it will be higher their perception toward the important the financial reports well and suitable on standard that be effect in SAK-EMKM.

The next of long in establishing company are influences toward the important arrangement financial report well and based on the standard that be effect in SAKEMKM, from the descriptive analysis above can be known that part of the informant in this research had held the enterprises more than 5 year (32 companies) and older than they had established the company of course need the bookkeeping in order to can make easier in commercial enterprise and prospect the company that they are running.

The measures of company or enterprises are also influence toward the important arrangement financial report well and suitable on standard that be effect in SAK-EMKM. That is due to all companies that became informant have employee more than 10 people, the enterprise asset are part of them estimating more than 100 million to 2.5 billion (32 companies). It is caused the entrepreneurs the micro trade, small and medium enterprises began to understand about the important arrangement financial report well and based on the standard that be effect in SAK-EMKM in managing the employees, asset, work scoring and financial works. For the company that felt the measure their enterprises still small, supposing that arrangement financial report have been needed because they still traded in their remembering in managing the company.

As said by Mr. Azun Nadlor in Surabaya through interviewed, he said: 
Yes, I did not care it was used or not but I made notes and financial report, even I am not capable in making the financial report. I did as well as possible that I could do it. Because of my weakness so far so it could appear the innovation and made changing (in making financial report) (Interviewed May 11, 2011).

The opinion above also agreed by Mrs. Wita in Gresik, through an interview she said:

For us, the financial report does not have big influence in enterprise, even the company is small enterprise, the report financial must be done, because we do not remember what we had done in the past time, even the note of financial report is not done every year and also it can make us difficult to make it. The bookkeeping becomes very important and give the safety for us, we could not be afraid by people. It is surely and the most thing that we get loan from the bank. (Interviewed May 21, 2018).

Of course that is difference to the 2 informant above, Mr. IImu in Mojokerto said:

Recently it is not necessary the bookkeeping as the accounting, because I don't have capable in making bookkeeping about financial report. Finally I made the financial report as I can do. The mostly as long as I remember I will do it. When I forgot in making financial repot I also felt confusing. But my enterprise has not been big one so it is not to necessary in making financial report that make the maker felt confuse.

Exactly, all government Regency/city become the object research through the employee of commercial company and micro enterprise stated that government had given workshops to arrange the financial report as said by Mr. IImul, all government of regency and city in which had become object through the assistance of commercial employee and micro enterprise said that government had given workshop to arrange. Actually, all regencies/cities become the object of research pass economic enterprise institution and micro enterprise explain that government had given workshops to arrange as explained by Mr. IImul (the chief of micro enterprises) and Mrs. Cholidah from Economic enterprise, the micro industry enterprises Gresik Regency when they were asked whether economic enterprise (Dinkop) and micro enterprise ever did the socialization or workshop about the financial for the micro trade, small and medium enterprises, then they answered:

If the financial is simple one so it is as only notes, included workshops of management become into one headline. Almost all entrepreneurs of the micro trade, small and medium enterprises sure that was the problem or obstacle 
for them in management, managing of center the financial with enterprise into one center. The workshops are from the scientists of Airlangga University, it can be also from banks institution. The workshops want to know only, due to the workshops are not urgent. (interview in 25 May 2018).

These workshops are done every sub district on continuity, and every sub district that every got workshop and assistance workshop about enterprise, in which divided into several villages with the difference and kind of workshop. While the assistance workshop often had weakness for the entrepreneurs during conducting the companies, for example in the financial assessing, packing process and other will explain to the institutions of government. But according to economic commercial, UM and industry department regency Gresik, most of them were lazy to do the financial report and there were willing to do the best. The common terms are they only accept the believing each other, give loan to people is very easy, but when the loans are addicted without being provident, started from it the beginning in making report and think that the important of bookkeeping, then finally omitted the bookkeeping, wholesale, and profit so the other people want to know how to reach it

\subsection{Understanding to the financial report in development model information system in financial report}

All informants did know about the standard of financial accounting entity micro, small and medium, these are because SAK-EMKA is new relative and be implemented in the beginning 2018 even though the formula hope to be imply in the beginning. SAK-EMKM actually is very easy for entrepreneurs the micro trade, small and medium enterprises in arrangement the financial report because the basically on history cost. By arrange only financial report that being the position of financial in the last period, reports benefits and suffer a financial loss in one periods and notes about financial report that content part of relevant holder.

Even though in simple and easy one in less socialization cause the informants did not know and understand about the standard of accounting, such as that said by Mrs. Ayu, the owner the micro trade, small and medium enterprises Candi Ratu in Batu, they explain:

"I never knew about accounting standard. I only know about bookkeeping not all. I did not understand whether same to accounting standard. I also never got or took part about socialization from the government or institution about socialization standard of accounting. I ever joined about workshop 
about financial report only. That is only income and output. (Interview 30 May 2018)

From result of examining regression above, it can be known that the background education influenced toward the understanding entrepreneur about arrangement financial report based on SAK-EMKM, so larger background of education from entrepreneur the micro trade, small and medium enterprises will influence higher understanding entrepreneur the micro trade, small and medium enterprises toward the arrangement financial report based on SAK-EMKM. This case can be understood when the owners company have capable in bookkeeping, so she/he will not do it again by himself so he does not need the other people such as Mrs. Eva Lusiana in Surabaya that said that:

"Fortunately, I graduated from accounting, so all cases can be done by myself. It starts incomes and output till report. Talking about SAK, I think it is a new one for me. I never know more about it but the other said that it is simpler in implementation. I will learn more about it. I think recently SAK is so complicated. (Interview 11 May 2018)

The long of entrepreneur establishing do not influence toward to understanding of entrepreneur arrangement financial report based on SAK-EMKM so long of entrepreneur establishing do not influence toward to understanding about arrangement financial report. It may be that in the younger the company so the owners pretend to learn and make arrangement financial report in order to know the development of and take the anticipative so the company still keep increasing about its selling. The younger company is commonly have the flexible attitude in the company and anticipative if it is compared to the old company. It is case done in order to the company get the new one in getting modal from the bank.

The measuring entrepreneurs do not influence understanding the owners toward the arrangement financial report based on SAK-EMKM so the company is not influence to higher understanding about the micro trade, small and medium enterprises toward the arrangement financial report based on SAK-EMKM.

Information and socialization about literacy of financial that given by the government toward entrepreneurs the micro trade, small and medium enterprises, so the more often the government give information and socialization about accounting financial standard for the small entrepreneurs will influence higher understanding entrepreneurs the micro trade, small and medium enterprises toward the arrangement financial report based on SAK-EMKM. Mostly the informants have not gotten yet about socialization from the government about SAK-EMKM, this case is caused SAK-EMKM as the new thing and 
have not had more reference that can be as reference as handout in making financial report.

The Government of Regency or city have not ever given workshop about SAK-EMKM, that ever they gave only simple bookkeeping and not yet focus on the appropriate with the accounting standard in recently. As said by Mr. Wartiono agency government economic enterprises and micro enterprise Surabaya city:

"Before the doing assistance about workshop, we coupled scientist from Airlangga University and Ciputra University and we hope they give material about the using of simple bookkeeping, to make using benefit of report profit and suffer a financial loss. After doing workshop, 6 people from agency government give assistance in the field in order to the building of enterprise (agency economic enterprises and personal unit Surabaya city also did) together access work together modal with the private company and national enterprise government institution (BUMN) as Telkom, Pelindo, Indonesia Bank. (in this case) the agency only connected the micro trade, small and medium enterprises (UMM) with national enterprise government institution (BUMN) with requirement get profit each other and the micro trade, small and medium enterprises do not face difficulties. (interview 11 May 2018).

When it is answered whether entrepreneurs the micro trade, small and medium enterprises had done the arrangement financial report well, she answered that part of them like it, but mostly they had used it (arrangement financial report) commonly who have not done the arrangement financial report are pioneers of entrepreneur, modal of financial must use for expensing of using enterprise modal so the modal is only taken around.

\subsection{Loan credit by the banking}

The result of research shows that the old enterprise, measure enterprise, frequency credit and guarantee have influence significant toward the credit loan by the bank, but the quality financial report do not influence to the loan credit by the bank.

Old of enterprise toward the loan credit by the bank caused by the owner bank relatively more believe with the old companies in establishing. It is cause that the generally company have been long probable they also have risk in low credit loan and they had been proof to the existence. While the measure of companies or enterprise has influence toward the credit loan by the bank. It is also aware by the debtor that still care the number 
of asset and large enterprise that still have by creditors that will become consideration in decide the number that will be given.

The interesting in this research is that the quality of financial report is not influence toward the loan credit by the bank. It is probably cause of the financial report is produced the micro trade, small and medium enterprises that has not examined because the obstacle and have not be capable in implementation in reality that they have been as creditor company. It can be caused by information that the presentation in financial report did not fulfill the standard of accounting financial recently, so it causes the owner of bank will be stop and distribute to another as the financial report, for example in the number of asset that be owned, number of financial/guarantee that is given, period the time credit and some also pass the survey directly by the owners of bank to the place of company or enterprise and observe the notes loan to the data base of bank that they have.

Based on the result of interview with informant and they never did the transaction loan in the bank with the reason that they have not had brave to borrow to the bank and could not be returned on time. This is the same to the result interview with Mr. Ibu Ana in Malang (interview at 17 May 2018) she said:

"actually, I want to borrow the modal and get loan from the bank, but I am afraid not to return on time, I am afraid that when the next time in returning the loan I don't have money to be used to return to the bank and of course the owners of bank ask me every time. If there is loan from other of bank I think it is better"

The comment is the same to that said by one of the informant, namely Mr. M. Yasin in Singosari Malang (interview 17 May 2018), he said that he also agree to have loan to the bank but he ever try to borrow the money in the bank but the requirements is complicated and to borrow of course need guarantee in loan.

The comment is the same to that said by one of the informant, namely Mr. M. Yasin in Singosari Malang (interview 17 May 2018), he said that he also agree to have loan to the bank but he ever try to borrow the money in the bank but the requirements is complicated and to borrow of course need guarantee in loan.

From the result of interview, is also got the data that mostly the informants get information about credit enterprise from the bank through publication that done by agency of bank with estimating 13 or $34.2 \%$. The number of loan credit that gotten and approval by the institution of bank as big as informant get loan between 25 million till 50 million, namely with 12 people or $31.6 \%$, while for other with 10 people get credit more than 
100 million and the other 1 people get loan from the bank 50 million till 100 million. The period of loan gets variation between 1-2 year, 3-4 year till are more than 5 year. The informant also explain the average give period to the bank in form certificate of land with variation value between 10-50 million and above 100 million, as had explained by $\mathrm{Mr}$. Eva Lusiana in Surabaya (interview 11 May 2018), the estimate of informants also explain that loan process in the bank enough easy and the process till the modal is approval and it does not need more time, the estimation in the count based on the day from 1 week.

The estimating loan that is given by the bank to the informant is used to develop the enterprise and according the informant that the loan is related to the negative with the increase their income.

\section{Conclusion and Suggestion}

\subsection{Conclusion}

Based on the result analysis that has reached in the discussion as result research, so this research can formulate in conclusion as below:

1. The level of education, background of education, the old of establishing company and measure company have influence in significant cases toward the perception entrepreneur the micro trade, small and medium enterprises to the important arrangement financial report well and right based on the standard the recently SAKEMKM.

2. Background of education and information and socialization about literacy of financial that given by the government influence toward to the understanding entrepreneur the micro trade, small and medium enterprises (UMKM), so more often government give information and socialization about the standard counting and socialization about financial accounting standard for the small entrepreneurs and will influence more to the high in arrangement financial report based on SAKEMKM, while the long of company in establishing and measure enterprise are not influence toward the arrangement financial report based on SAK-EMKM

3. Result of research shows that the long enterprise, measure enterprise, the period credit and guarantee have significant influence toward the loading credit by bank, but the quality financial report is not influence to the loan of credit by the bank. 


\subsection{Suggestion}

SAK-EMKM made regulation of accounting is simpler from SAK-ETAP, because the regulation had arranged the general transaction that done by EMKM and the basic measure used history cost. The implementation nowadays is still accept and felt by micro, small and medium enterprises that become the subject from the accounting financial standard, so the trouble in making is appear. The big financials are report and also about the low of understanding the entrepreneurs toward the accounting standard in effect it. Socialization should take part by many people are important because the passive implementation and standard accounting advantage for development the micro trade, small and medium enterprises.

The owners of bank should begin to imply in bookkeeping to the requirement in giving credit through quality financial report based on the standard that effect in, not only the focus on the target of credit reaching that given to customers. It is important because without system or mechanism as it, the micro trade, small and medium enterprises do not feel that the financial report is important

The weakness from this research is the less of understanding the informant in the important the using note in enterprise transaction and important the financial report that based on the recently accounting standard. The other weakness is the limit number informants and also object of research that only focus on regencies/cities that have PDRB above of average from province. The other things that need to be repaired in the next research is need to involve the informants in this research in order to the data is present on validity one.

\section{References}

[1] Chandra, A. and Ardhan. (2016). BI: Baru 22\% UMKM yang memiliki akses ke Perbankan, Detik Finance. Retrieved from: https://finance.detik.com/moneter/d3283575/bi-baru-22-umkm-yang-memiliki-akses-ke-perbankan (accessed on April 16, 2017).

[2] Anggraeni, J. (2016). Standar AkuntansiKeuangan (SAK) Entitas Mikro Kecil\& Menengah: Terobosan IAI. Majalah Akuntan Indonesia. IAI. Edisi Pebruari.

[3] Bank Indonesia. (2015). Profil Bisnis Usaha Mikro, Kecil dan Menengah (UMKM). Jakarta: Kerjasama LPPI dengan Bank Indonesia.

[4] Koperasi, D. and UMKM Provinsi Jawa Timur. (2017). Jumlah UMKM Di Provinsi Jawa Timur Menurut Sektor dan Kabupaten/Kota. Retrieved from: 
http://www.diskopumkm.jatimprov.go.id/view-media.php?pages=content\&id=57 \&bidang= (accessed on May 16, 2017).

[5] Ikatan Akuntan Indonesia. (2016). Standar Akuntansi Keuangan Entitas Mikro, Kecil, dan Menengah. Jakarta: IAI.

[6] Ikatan Akuntan Indonesia. (2016). Standar Akuntansi Keuangan Entitas Tanpa Akuntabilitas Publik. Jakarta: Cetakan Keenam, IAI.

[7] Iswoyo, A. and Ermawati, Y. N., and Alfi, W. R. (December 6-7, 2016). Review of the Implementation of Government Regulation No. 46 Year 2013: Contributions and Constraint for SMEs. Proceeding of International Conference on Economics, Business and Social Sciences (ICEBUSS), Malang.

[8] Kurniawanysah, D. (December 17, 2016). Penerapan Pencatatan Akuntansi dan Penyusunan Laporan Keuangan Berdasarkan SAK ETAP pada UMKM Desa Gembongsari Kecamatan Kalipuro Kabupaten Banyuwangi. Prosiding Seminar Nasional "Dinamika Global: Rebranding Keunggulan Kompetitif Berbasis Kearifan Lokal", Universitas Jember.

[9] Narsa, I. M., Widodo, A., and Kurnianto, S. (December 2012). Mengungkap Kesiapan UMKM dalam Implementasi Standar Akuntansi Keuangan Entitas Tanpa Akuntabilitas Publik (PSAK-ETAP) untuk Meningkatkan Akses Modal Perbankan. Majalah Ekonomi. Tahun XXII, No. 3. 